\title{
A IMPORTÂNCIA DO TRABALHO PREVENTIVO DA POLÍCIA MILITAR NAS ESCOLAS CONSCIENTIZANDO SOBRE BULLYING
}

\author{
THE IMPORTANCE OF MILITARY POLICE PREVENTIVE WORK IN SCHOOLS \\ AWARENESS ABOUT BULLYING
}

\author{
Luiz Ricardo dos Santos ${ }^{1}$
}

\begin{abstract}
RESUMO: O presente artigo trata-se de uma pesquisa de caráter bibliográfico em dados primários e secundários como base para o desenvolvimento do estudo, no qual foi feita análise de literatura em livros, artigos, periódicos, jornais e matérias online, com objetivo geral de apresentar as várias formas de bullying escolar é uma forma de violência que assola do mundo, e no Brasil não é diferente. O Direito Penal utilizado como forma de pacificação social como última ratio, não poderia ficar indiferente a tal violência que fere bens jurídicos da mais alta importância. Tem por objetivo o presente trabalho investigar que mesmo inexistindo um tipo penal específico denominado bullying, a legislação penal pátria possui tipos penais que protegem bens jurídicos semelhantes àqueles atingidos pela prática do Bullying escolar. Foi utilizado no presente trabalho o método dialético e indutivo além de doutrinas e jurisprudência pertinentes à matéria. Dando seguimento, foi abordado a origem histórica do bullying, seu conceito e características, o papel do professor e do operador do Direito, além de ressaltarmos as consequências físicas e psicológicas do bullying, citando pesquisas nacionais sobre o fenômeno, e elencando pessoas famosas que sofreram com o bullying escolar e conseguiram superar. Discorreu-se também sobre a responsabilização dos menores quando da prática de bullying, elencando as medidas sócio educativas que podem ser submetidos. $\mathrm{Na}$ terceira parte demos conta da finalidade do Direito Penal e sua aplicação multidisciplinar com outras ciências, e ainda citamos tipos penais que se adéquam perfeitamente a casos de bullying, ressaltando que a prevenção é um ótimo caminho. Por fim, comprovou-se cientificamente com esta pesquisa a correção da hipótese quanto a real possibilidade de aplicação do Direito Penal aos casos de bullying escolar que ocorrem no Brasil, ante a inexistência de legislação específica com o nomem iuris de bullying escolar.
\end{abstract}

Palavras-chave: Bullying. Direito Penal. Responsabilização.

ABSTRACT: The present article is a bibliographic research on primary and secondary data as a basis for the development of the study, unqualified analysis of literature was made in books, articles, periodicals, newspapers and online materials, with the general objective of presenting as Various forms of school bullying are a form of violence that plagues the world, and in Brazil it is no different. The Criminal Law used as a form of social pacification as the ultimate ratio, could not remain indifferent to such violence that hurts legal assets of the highest importance. The objective of the present work is to investigate that even though there is no specific criminal type called Bullying, the national criminal law has types that protect legal assets similar to those affected by the practice of school bullying. In the present work, the dialectic and inductive method was used in addition to doctrines and jurisprudence relevant to the matter. As a follow-up, the historical origin of Bullying, its concept and characteristics, the role of the teacher and the operator of the Law were addressed, in addition to highlighting the physical and psychological consequences of Bullying, citing national research on the phenomenon, and listing famous people who suffered with school bullying and managed to overcome. It was also discussed the responsibility of minors when bullying, listing as socio-educational measures that can be found. In the third part, we realized the need for Criminal Law and its multidisciplinary application with other sciences, and we also mentioned types of criminals that are perfectly suited to cases of bullying, emphasizing that prevention is an optimal path. Finally, it was scientifically proven with this research a correction of the hypothesis as to a real possibility of applying Criminal Law to cases of school bullying that occurs in Brazil, given

1 Graduado do Curso de Administração de Empresas e administração Rural, Pós-graduado em Direito Ambiental e direito Militar, Armazenagem de grãos e Segurança alimentar, cursando Agronomia pela Universidade do Norte do Paraná - Bandeirantes-Pr. E-mail: rikardoshow@hotmail.com. 
the lack of specific legislation with the name of school bullying instrument.

Keywords: Bullying. Criminal Law. Accountability.

\section{INTRODUÇÃO}

O bullying, palavra de origem inglesa, que representa inúmeras agressões psicológicas e físicas, como ameaças de causar mal injusto e grave, apelidos, xingamento, roubos, das quais todas apresentam adequação típica no Código Penal. Tais agressões estão presentes em todos os ambientes em que existem relações interpessoais, contudo o presente estudo aborda o Bullying no ambiente escolar desde o ensino fundamental ao superior.

Os estudos sobre o bullying tiveram início na década de 1970 realizado por Dan Olweus na Universidade de Bergen na Noruega. Tais pesquisas se tornaram notórias em 1983, quando o Governo daquele país promoveu apoio a tais estudos por conta de ocorrências de suicídios envolvendo adolescentes no ambiente escolar.

No Brasil, as pesquisas efetuadas por Cleodelice Aparecida Zonato Fante, autora do Livro "Fenômeno bullying: Como prevenir a violência nas escolas e educar para a paz" foi quem desejou estudar e aprofundar os estudos sobre bullying escolar no Brasil. Iniciou ainda no ano 2000 na região de São José do Rio Preto, Estado de São Paulo o "Programa Educar para Paz", o qual findou no ano de 2003, tendo a participação de dois mil alunos. Tal programa que foi pioneiro no Brasil, conseguiu reduzir os índices de bullying por meio de estratégias que conscientizaram os pais, alunos e funcionários a combater tal mal.

Na qualidade de ciência, o Direito Penal tem como objetivo primaz dar uma resposta aos anseios da sociedade, que roga por uma punição quando do cometimento de práticas que ferem bens jurídicos de suma importância.

Buscou-se com a presente pesquisa proporcionar a comunidade escolar e aos operadores do Direito, ferramentas adequadas para interpretarem casos de bullying frente à ciência educacional e do Direito, tomando medidas legais pertinentes ao que o caso requer.

Em suma a referida pesquisa fornecerá ferramentas para o operador do Direito e para os componentes do organismo escolar poderem lidar com a ocorrência de casos de bullying, e promoverem uma adequação tipológica frente aos tipos penais incriminadores já existentes em nosso Código Penal e demais normas positivas correlatas afetas à matéria.

Em referência ao problema, a questão que se coloca é como se processa a responsabilização penal entre alunos (maiores ou menores de idade), frente a atos por eles praticados tidos como casos de bullying, ante a não existência de um tipo penal incriminador em nosso ordenamento jurídico com tal nomen iuris. 
A hipótese do presente trabalho teve enfoque quanto a não podemos negar a possibilidade de aplicação do Direito Penal aos casos de bullying escolar que ocorrem na atualidade no Brasil, motivando simplesmente ao fato de inexistir uma legislação específica, pois as condutas praticadas e tidas como bullying se acomodam perfeitamente aos tipos penais já existentes em nossa legislação penal.

Tendo em vista o objetivo proposto, em uma primeira parte discorremos sobre a origem histórica do bullying, além de conceituá-lo e delimitar suas características, bem como comentamos sobre o bullying escolar e o papel do professor e do operador do Direito além de ressaltarmos as consequências físicas e psicológicas do bullying, citando, outrossim, pesquisas nacionais sobre o fenômeno em estudo, e elencando pessoas famosas que sofreram com o bullying escolar e conseguiram superar.

$\mathrm{Na}$ segunda parte, discorrermos sobre a responsabilização dos menores de idade quando da prática de bullying, elencando as medidas sócio educativas a que podem ser submetidos por conta de disposição legal expressa no Estatuto da Criança e do Adolescente.

$\mathrm{Na}$ terceira parte demos conta da finalidade do Direito Penal e sua aplicação multidisciplinar com outras ciências, e ainda citamos tipos penais que se adaptam perfeitamente a casos de bullying, e ressaltamos que a prevenção é um ótimo caminho.

Para consecução do presente trabalho, foi utilizada a abordagem metodológica, dialética e indutiva, além de pesquisa bibliográfica, e inclusão de obras de doutrinadores, bem como periódicos especializados e jurisprudências de nossos Tribunais.

O trabalho apresentado tem a singela pretensão de lançar novas luzes para uma caminhada muito mais profunda sobre o bullying escolar, portanto, esta pesquisa propõe-se a investigar o bullying escolar, esclarecendo a importância em conhecer que inúmeras condutas tidas como tal, se amoldam às figuras (verbos) tipicamente esculpidas no ordenamento penal pátrio, portanto, passíveis se sanção penal.

Para, em sede de considerações finais, comprovar-se, cientificamente, a correção da hipótese quanto a real possibilidade de aplicação do Direito Penal aos casos de bullying escolar que ocorrem no Brasil, ante a inexistência de legislação específica, pois as condutas praticadas e tidas como bullying se ajustam perfeitamente aos tipos penais já existentes.

I Breve histórico sobre as investigações em torno do bullying

Segundo Fante (2005), os autores que tratam sonbre o bullying são chamados de "bullies". O bullying nos apresenta ser tão antigo quanto a instituição escolar, mas só a partir dos anos 70 é que começou a ser estudado de forma sistemática e científica na Suécia, espalhando seu estudo 
por toda a Europa. Na Noruega grande era a preocupação geral sobre o tema, principalmente apresentada pelos meios de comunicação, contudo as autoridades da área educacional não tinham tanto interesse assim. Somente depois de 1982, quando uma criança e um adolescente de 1o e 14 anos respectivamente se mataram, talvez vítimas dos colegas na escola, ocorreu uma mobilização de ordem nacional em toda Noruega no combate ao Bullying:

Esse fato originou grande tensão e divulgação nos meios de comunicação, atingindo a população de maneira geral, fazendo com que o Ministério da Educação da Noruega, em 1983, fizesse uma campanha em escala nacional contra os problemas entre agressores e vítimas (FANTE, 2005, p. 45)

Merece destaque segundo Arrieta (2000, p. 32), as pesquisas feitas na Noruega por Dan Olweus, que escreveu em 1993 o livro Bullying at Scholl. No ensinamento de Fante (2005), Dan Olweus foi o primeiro pesquisador que relacionou determinadas atitudes agressivas cometidas por estudantes com o termo Bullying, pois, procurou diferenciar determinadas brincadeiras típicas da infância de determinados atos cruéis que ocorriam nas escolas, e em nada tinha a ver com brincadeiras pueris, desenvolvendo critérios específicos para poder identificar as agressões que ocorriam entre alunos. (PEREIRA, 2002).

O pesquisador Dan Olweus conseguiu tabular, inúmeros dados estatísticos:

[...] tendo como base um questionário composto de 25 (vinte e cinco) questões entrevistou 84 mil (oitenta e quatro mil) estudantes em diversos níveis e períodos escolares, 400 (quatrocentos) professores e i ooo (Mil) pais. Com a realização das entrevistas, Dan Olweus pôde perceber a natureza do bullying, suas possíveis origens, ocorrências, formas de manifestação, extensão e características. (LEÃO, 2010, p. 121)

No Brasil, desde o final da década de noventa, pesquisas tem sido feitas buscando uma minimização da realidade encontrada em nossas escolas, que sofrem cotidianamente com o Bullying, e dentre vários trabalhos hoje existentes citamos o que foi pioneiro, de Fante e Pedra (2008, p. 49-5o), os quais brilhantemente pesquisaram:

[...] um universo de 2 mil alunos de escolas públicas e privadas da região de São José do Rio Preto. Os resultados foram surpreendentes: 49\% dos participantes estavam envolvidos no fenômeno. Desses 22\% eram vítimas, $15 \%$ agressores e (12\%) vítimas agressores.

Com a evolução social o estudo do fenômeno Bullying tornou-se uma necessidade, pois, sua ocorrência se tornou uma constante no meio escolar causando enormes prejuízos de ordens diversas, e neste sentido o ensinamento de Melo, (2010, p. 24), dá conta que na atualidade muito se tem feito, mas o que "[...] há de novo no bullying é o estudo sistematizado numa metodologia científica, utilizando-se métodos e procedimentos adequados e atribuindo-se uma importância nova aos comportamentos antigos, sobretudo no âmbito escolar".

I.2 Conceitos de bullying especialmente na normativa pátria 
O Bullying não apresenta identificação semelhante em todos os países em que é estudado. $\mathrm{Na}$ Noruega e na Dinamarca é conhecido como "Mobbing" que tem o significado de tumultuar, na Suécia e Finlândia o termo utilizado é "Mobbning". Já na Itália tem o conceito de "prepotenza", na Espanha "intimidación” e no Japão é conhecido como "yjime" (FANTE, 2005).

A pesquisadora Fante (2010), conceitua tal fenômeno da seguinte forma:

Bullying é um termo utilizado na literatura psicológica anglo-saxônica, para designar comportamentos agressivos e antissociais, nos estudos sobre o problema da violência escolar. Universalmente, o bullying é conceituado como sendo um "conjunto de atitudes agressivas, intencionais e repetitivas, que ocorrem sem motivação evidente, adotadas por um ou mais alunos contra outro(s), causando dor, angústia e sofrimento, e executadas dentro de uma relação desigual de poder, tornando possível a intimidação da vítima.

Legisladores no estado do Paraná e do Distrito Federal, preocupados com o avanço do mal do bullying, positivaram conceitos semelhantes do que pode ser considerado bullying, demonstrando que já existe em solo tupiniquim um conceito sobre tal mal, a saber:

\section{$[\ldots]$}

Art. $2^{\circ}$ Para os efeitos desta Lei, considera-se bullying a violência física ou psicológica, praticada intencionalmente e de maneira continuada, de índole cruel e de cunho intimidador e vexatório, por um ou mais alunos, contra um ou mais colegas em situação de fragilidade, com o objetivo deliberado de agredir, intimidar, humilhar, causar sofrimento e dano físico ou moral à vítima. (DISTRITO FEDERAL, 2012)

Na normativa no orbe estadual:

Parágrafo único. Entende-se por bullying atitudes de violência física ou psicológica, intencionais e repetitivas, que ocorrem sem motivação evidente, praticadas por um indivíduo (bully) ou grupos de indivíduos, contra uma ou mais pessoas, com o objetivo de intimidá-la ou agredi-la, causando dor e angústia à vítima, em uma relação de desequilíbrio de poder entre as partes envolvidas. (PARANÁ, 2012)

Em brilhante artigo, Fante (2012) nos ensina que existe um consenso entre os pesquisadores brasileiros em utilizarem o termo bullying somente na relação entre adolescente e crianças, sendo que entre pares adultos se utiliza o termo "assédio moral".

Apesar do longo tempo de estudo e de inúmeras publicações científicas, ainda não existe uma palavra na língua portuguesa que expresse todos os significados do termo inglês bullying:

Como não existe na língua portuguesa uma tradução para a palavra inglesa bullying capaz de expressar todas as situações possíveis que o vocábulo denota optamos por manter o termo original em inglês. De acordo com o dicionário Michaleis, bullying significa tiranização, ameaça, intimidação, opressão. (SIMMONS, 2004, p. 9)

O Conselho Nacional de Justiça (CNJ), no ano de 2010 se atentando para o grave problema que é o bullying, lançou uma cartilha objetivando auxiliar pais e educadores preventivamente, dando conta que tal termo de origem inglesa é: 
[...] utilizado para qualificar comportamentos agressivos no âmbito escolar, praticados tanto por meninos quanto por meninas. Os Atos de violência (física ou não) ocorrem de forma intencional e repetitiva contra um ou mais alunos que se encontram impossibilitados de fazer frente às agressões sofridas. Tais comportamentos não apresentam motivações específicas ou justificáveis. Em última instância, significa dizer que, de forma natural, os mais forte utilizam os mais frágeis como meros objetos de diversão, prazer e poder, com o intuito de maltratar, intimidar, humilhar e amedrontar suas vítimas. (SILVA, A., 2oroa, p. 7).

Ainda objetivando identificar condutas que sejam consideradas bullying, as condutas omissivas, ou seja, aquelas que pelo simples fato de não agir, também podem ser consideradas Bullying, sendo neste sentido o ensinamento de Calhau apud Fante (2010):

Ele pode ser produzido com atos de ignorar, "dar um gelo" ou isolar a vítima. Se provocados por um grupo de alunos numa sala de aula podem ser devastadores para a autoestima de uma criança, por exemplo. Em geral, o bullying praticado com omissão é mais afeto ao praticado por meninas e é bem sutil. É quase invisível. Se você analisar o ato isolado ele pode não significar nada, mas são como pequenas agressões, que pouco a pouco vão minando a integridade psicológica da vítima.

1.3 A Identificação do bullying e outros critérios

Dan Olweus, da Universidade de Bergen, na Noruega (1978 a 1993, apud Fante; Pedra, 2008, pg. 39) estabeleceu alguns critérios básicos para identificar as condutas bullying e assim, diferenciá-las de outras formas de violência e das brincadeiras próprias da idade.

Os critérios são: ações repetitivas contra a mesma vítima num período prolongado; desequilíbrio de poder, o que dificulta a defesa da vítima; ausência de motivo que justifique os ataques. Por ações repetitivas entendem-se quando os ataques são desferidos contra a mesma vítima num período, podendo variar de duas ou mais vezes no ano letivo.

Embora pareça que seja pouco, deve-se considerar a desagradável e aversiva experiência vivenciada pela vítima, o medo, que se torna constante, principalmente de que o ataque volte a acontecer. Cabe, então, à vítima mobilizar sentimentos como: ansiedade, medo, insegurança, raiva, além de tensão, constrangimento, receio de fazer uma pergunta ao professor e ser alvo de 'zoação'.

Assim, para a vítima é preferível calar-se ou isolar-se dos demais na tentativa de minimizar seu sofrimento, mesmo quando está longe do ambiente escolar, a vítima continua lembrando-se dos episódios e somatizando-os, como se tivesse na presença de seus agressores.

Sendo então os maus-tratos verbais, por meio dos apelidos depreciativos as ações mais comumente realizadas pelos que praticam o bullying, no entanto, os agressores não param por aí, pois quando a vítima mostra-se ofendida ou pede para ser deixada em paz, acabam utilizando 
outras formas de maus-tratos, como intimidações, perseguições, chantagens, ou até mesmo maus-tratos físicos, para que a vítima não denuncie seus atos.

O comportamento bullying pode ser identificado em qualquer faixa etária e nível de escolaridade, portanto, desde os três ou quatro anos é possível perceber o comportamento abusivo, manipulador, dominador e, por outro lado, passivo, submisso e indefeso. (FANTE; PEDRA, 2008)

Entretanto, a maior incidência está entre os alunos do sexto ao nono ano (quinta a oitava série), período em que, progressivamente, os papéis dos protagonistas se definem com maior clareza. No entanto, é possível encontrar grupos de alunos de séries avançadas submetendo colegas de séries inferiores aos seus ataques ou fazendo com que entreguem dinheiro, lanche ou pertences.

Ainda promovem o psicoterrorismo, disseminando o medo e o terror dentro e fora da escola por meio de ameaças, intimidações, perseguições ou dos maus-tratos físicos e verbais.

Alessandro Costantini - pesquisador italiano (2006, citado por Fante; Pedra, 2008, p. 46) diz que em uma pesquisa americana concluiu-se que a agressividade apresenta um aumento linear dos três aos catorze anos e o emprego da agressão física aumenta a partir dos dez anos.

Concluiu também que a violência e as atitudes antissociais se incrementam dos doze anos em diante e que as condenações penais decorrentes dos comportamentos violentos, ocorrem em maior grau dos dezoito aos vinte anos, e pode se prolongar por diversos anos em graves comportamentos agressivos.

Percebe-se, então que o bullying vem se propagando cada vez mais na educação infantil e no ensino fundamental, e a maioria dos casos ocorre nos primeiros anos escolares, porém a sua intensidade e o agravamento dos episódios aumentam conforme aumenta o grau de escolaridade. "E o fenômeno continua crescendo em todo o mundo, somente no Brasil em 2007, a média de envolvimento dos estudantes brasileiros era de $45 \%$ acima dos índices mundiais", sinaliza Fante e Pedra (2008, p. 50). O mais preocupante é que as crianças na mais tenra idade escolar já apresentam envolvimento e evidências de prejuízos sofridos. (FANTE; PEDRA, 2008)

Acredita-se que o aumento dos índices deve-se à tendência da vítima em reproduzir os maus-tratos sofridos. Assim, o fenômeno se expande e envolve um número crescente de alunos, há também motivos variados que impulsionam o aumento das práticas de bullying nas escolas ou a integração das vítimas em grupos que se dedicam ao assédio.

Podendo-se citar: o estímulo à competitividade e ao individualismo, principalmente decorrente da pressão exercida pela família e a escola quanto à obtenção de resultados, especialmente nos vestibulares; a banalização da violência e a certeza da impunidade; o 
desrespeito e a desvalorização do ser humano, evidenciados em diversos contextos; a educação familiar permissiva e a ausência de limites e, sobretudo, a deficiência ou ausência de modelos educativos baseados em valores humanos, orientando-os para a convivência pacífica, solidariedade, cooperação, tolerância e respeito às diferenças, que despertam os sentimentos de empatia, afetividade e compaixão nos seres humanos. (FANTE; PEDRA, 2008)

Independentemente se a escola for pública ou privada, sua localização, seu turno ou seu poder aquisitivo da comunidade escolar, o bullying está presente em (I00\%) das escolas. Os locais onde ocorrem os ataques podem ser: pátios de recreio, playground, banheiros, corredores, salas de aula, bibliotecas, quadras esportivas, salas de informática, laboratórios e imediações das escolas. Podem ocorrer também em outros locais fora da escola, como condomínios, lan houses, shoppings e outros locais comuns aos alunos. Contudo, no Brasil as pesquisas apontam a maior incidência para a sala de aula.

Essa incidência se deve ao fato de que por ser um tema novo de discussão no meio educacional brasileiro, em que a maioria dos professores desconhece a relevância do fenômeno e não sabe como agir ao se deparar com a questão, acabam agindo de acordo com suas próprias experiências, ou seja, muitos acreditam ser obullying necessário para o amadurecimento do indivíduo.

Outros não dão a devida importância por acreditarem que 'são brincadeiras próprias da idade', sem maiores consequências; há aqueles que pensam que os próprios alunos devem resolver seus problemas, sem intromissão dos adultos.

Contudo, todo professor, treinado ou não para lidar com o bullying, é capaz de observar as relações interpessoais e perceber os sinais que são emitidos por aqueles que se sentem incomodados ou vitimizados. (FANTE; PEDRA, 2008)

I.4 Espécies e características de bullying

Vinha apud Elboux (2012) também traz um conceito do que seja bullying, contudo de forma interessante apresenta suas características:

[...] o termo é utilizado para designar atos agressivos entre os estudantes, e sua prática apresenta mais de uma característica típica. Os aspectos principais relacionados ao bullying são quatro: há intenção do(s) autor(es) em ferir; são atos repetidos contra um ou mais alvos constantes; há uma espécie de concordância do alvo sobre o que pensam dele (por isso há crianças obesas que são alvos e outras não) e há um público que prestigia as agressões - os ataques são escondidos dos adultos, mas nunca dos pares. "Vale a pena destacar que esses espectadores alimentam o problema, dando poder, prestígio [ao autor], por compactuarem com o que ocorre. Muitas vezes, este público participa com risos e olhares, mantendo a imagem de que isto é divertido e que pertence ao grupo dos mais poderosos ou, pelo menos, não faz parte do grupo dos mais 
'fracos'. Há também o medo de se tornar a 'próxima vítima'. É preciso ficar do 'lado do mais forte'.

Neto (2004, p. 36) em sua doutrina classifica o Bullying em dois tipos, a saber:

O bullying é classificado como direto quando as vítimas são atacadas diretamente, ou indireto, quando as vítimas estão ausentes. São considerados bullying direto os apelidos, agressões físicas, ameaças, roubos, ofensas verbais ou expressões, ou gestos que geram mal-estar aos alvos. São atos utilizados com uma frequência quatro vezes maior entre os meninos. O bullying indireto compreende atitudes de indiferença, isolamento, difamação e negação aos desejos, sendo mais adotados pelas meninas.

Contudo, Martins (2005) classifica três formas de bullying. A primeira envolve tipos de comportamentos diretos e físicos, o que inclui atos como agredir fisicamente, roubar ou danificar propriedade alheia, extorquir dinheiro, constranger de forma a obrigar a realização de atividades servis. A segunda forma está relacionada a comportamentos diretos e verbais, como insultar, apelidar, fazer comentários racistas, homofônicos ou que digam respeito a qualquer diferença no outro. E finalmente, há os comportamentos indiretos, como promover a exclusão sistemática da pessoa, ou espalhar boatos.

Na doutrina de Debarbieux e Blaya, as escolas podem ser locais que possibilitam maiores ou menores oportunidades para a ocorrência de intimidações, e "em termos da natureza do ambiente escolar e do tipo de valores éticos que ali prevalecem de haver ou não uma política escolar que de fato funcione e sanções contra a prática da intimidação". Portanto, a escola apresenta um ambiente social propício para a ocorrência dobullying. (DEBARBIEUX e BLAYA,2002, p. 192)

O Bullying se encontra presente em vários locais, como academias, clubes, mas é na escola e ai se entenda também o ensino universitário que mais se destaca, sendo ainda considerado um problema mundial, e aquelas instituições que afirmam não possuir casos de Bullying em seu meio, não conhecem a realidade de tal problema, fechando os olhos, fato grave que leva a ocorrência de inúmeros prejuízos à educação.

A diferença do bullying escolar com outros tipos de violências é o fato de ser praticado repetidamente e de forma sistemática e dolosa (livre e consciente) contra outro aluno mais vulnerável, ficando evidente o desequilíbrio de forças entre os envolvidos. O Bullying pode ser considerado uma subcategoria de um tipo específico de violência que abrange muito mais do que desentendimentos corriqueiros que ocorrem no seio da escola envolvendo estudantes. É uma violência que pode levar vítimas ao suicídio. (GOMES, 2012).

Podemos identificar casos de bullying na escola, por meio de três critérios segundo a doutrina de Calhau (2009, p. 32), que nos dá conta do ensinamento do pesquisador norueguês Dan Olweus, precursor nos estudos sobre o bullying, sendo os seguintes: 
- Ações repetitivas contra a mesma vítima num período prolongado de tempo;

- Desequilíbrio de poder, o que dificulta a defesa da vítima;

- Ausência de motivos que justifiquem os ataques.

Conhecendo tais critérios é possível ao operador do Direito, o professor, o pedagogo enfim todos aqueles que por obrigação funcional se virem frente a tal problema, conseguirem distinguir o bullying daquelas outras formas de violência que ocorrem pontualmente, como uma invasão da escola por pessoas desconhecidas para agredir um estudante específico.

Objetivando identificar as pessoas envolvidas com o bullying, é possível identificar três personagens em sua composição: agressor, vítima e espectador, sendo que Fante apud Calhau (2009, p. 7), apresentam uma classificação dos papéis que os protagonistas desempenham quando da prática deste tipo de violência:

- A vítima típica: que serve de bode expiatório para um grupo;

- A vítima provocadora: que provoca reações que não possui habilidades para lidar;

- A vítima agressora: que reproduz os maus-tratos sofridos;

- O agressor: que vitimiza os mais fracos;

- O espectador: que presencia os maus-tratos.

Como já citado em pesquisas, a maior incidência da violência em cito é entre crianças e adolescentes que frequentam o ensino fundamental e médio, contudo os estudantes universitários não estão imunes a tão odiosa prática. O trote visto como um ritual de passagem, por muitos aceitos e suportado por outros, nada mais é que a prática de bullying. A violência nas escolas nas últimas décadas cresceu muito em todas as sociedades, sendo tal questão preocupante devido à grande incidência em todos os níveis de escolaridade. (FANTE, 2005 p. 20)

A renomada pesquisadora (2008) ressalta que a origem dos trotes é incerta, mas existem registros de sua ocorrência no século XVII, na França. No Brasil se tem notícia que os primeiros trotes violentos aconteceram no século XIX. Em 1831, um estudante foi morto a golpes de bengala durante um trote na Universidade de Recife. Em 185o, os alunos da Faculdade de Direito do Largo São Francisco reagiram ao trote e a intervenção da polícia foi necessária para controlar a situação. As Universidades tentam alterar as práticas quando da recepção dos novos alunos, mas os jornais cotidianamente registram situações violentas.

O combate ao bullying escolar vai além dos portões da escola, sendo considerado como um mal que afeta toda a sociedade, sendo a responsabilidade para seu combate de vários órgãos, multidisciplinarmente. 
2. O papel do professor e do operador do Direito

Na qualidade de operador do Direito e curador da infância e adolescência, o Ministério

Público é uma instituição incumbida em defender os interesses da sociedade, contudo:

É certo que nem todas as áreas de atuação do Ministério Público admitem a "mediação de conflitos", mas o campo escolar, em muitos casos, é uma das possibilidades onde o promotor de justiça pode com sua discricionariedade, dedicação e criatividade, contornar uma série de questões que, se levadas ao Poder Judiciário, não encontrarão uma resposta mais adequada para a comunidade escolar, como também, trarão confusão, desconforto e perplexidade a todos que giram em torno daquela escola. (CALHAU, 2012, p. 03)

É recorrente a assertiva que a violência na escola tem aumentado muito e os educadores não estão conseguido sanar tal nefasto problema (ABRAMOVAY e RUA, 2002; CHAUÍ, 1999; FANTE, 2005; JARES, 2002). Evidencia-se, portanto com o arrazoado, a importância do conhecimento do professor sobre o fenômeno Bullying e a forma de como agir em sala de aula.

$\mathrm{Na}$ cartilha lançada pelo $\mathrm{CNJ}$, podemos encontrar orientações àqueles que são responsáveis pelos estabelecimentos de ensino quando da ocorrência de casos de Bullying, mas que podem ser de grande valia se conhecidas por outros profissionais que por uma ocasião ou outra se virem frente a tal problema:

A escola é corresponsável nos casos de bullying, pois é lá onde os comportamentos agressivos e transgressores se evidenciam ou se agravam na maioria das vezes. A direção da escola (como autoridade máxima da instituição) deve acionar os pais, os Conselhos Tutelares, os órgãos de proteção à criança e ao adolescente, etc. Caso não o faça poderá ser responsabilizada por omissão. Em situações que envolvam atos infracionais (ou ilícitos) a escola também tem o dever de fazer a ocorrência policial. Dessa forma, os fatos podem ser devidamente apurados pelas autoridades competentes e os culpados responsabilizados. Tais procedimentos evitam a impunidade e inibem o crescimento da violência e da criminalidade infanto-juvenil. (SILVA, A., 2oloa, p. I2)

Apesar do acima exposto, Schelb apud Calhau (2009, p. 83) ressalta que uma intervenção, [...] "deve ser ponderada, na medida em que, se, por um lado, deve fazer cessar a humilhação, por outro, deve estimular na vítima dobullying a capacidade de autodefesa evitando uma superproteção prejudicial”.

Por conta do caráter multidisciplinar, já evidenciado e que versa quanto ao tratamento do bullying, bem como a imperiosa necessidade de as escolas estarem preparadas para lidar com o tema atual e de certa complexidade, Calhau (2009, p. 32) enfatiza que:

[...] atualmente um grande número de escolas mantém em seus quadros pedagogos e psicólogos, que, em sendo chamados para ajudar, poderão contribuir muito com a solução dos problemas. A orientação deve nortear a ação desses profissionais. Chamar a polícia e o Ministério Público, a meu ver, somente nos casos mais graves. A solução, dentro do possível, deve ser conseguida compartilhando o problema com o grupo de alunos, tendo em vista 
que os alunos tendem a voltar a praticar os atos de bullying assim que se colocarem sem supervisão.

$\mathrm{Na}$ mesma linha de pensamento da Suso autora, Joaquim (2009, p. 234) assevera que:

Cabe, também, às instituições escolares, se necessário, reprimir atos de indisciplina praticados por alunos e aplicar as penalidades pedagógicas nos casos previstos no regimento escolar ou interno. Entretanto, deve esgotar todos os recursos, socio pedagógicos a ela inerente, inclusive ter uma equipe especializada de profissionais, como psicopedagogos e profissionais afins, para atuar de forma preventiva nos distúrbios ou problemas de aprendizagem.

A cartilha do CNJ de forma pontual nos dá conta de como perceber que um estudante está sendo vítima de bullying:

No recreio encontram-se isoladas do grupo, ou perto de alguns adultos que possam protegê-las; na sala de aula apresentam postura retraída, faltas frequentes às aulas, mostram-se comumente tristes, deprimidas ou aflitas; nos jogos ou atividades em grupo sempre são as últimas a serem escolhidas ou são excluídas; aos poucos vão se desinteressando das atividades e tarefas escolares; e em casos mais dramáticos apresentam hematomas, arranhões, cortes, roupas danificadas ou rasgadas. (SILVA, A., 2010a, p. Io)

Tal cartilha elenca ainda como se pode identificar o autor do Bullying:

$\mathrm{Na}$ escola os bullies (agressores) fazem brincadeiras de mau gosto, gozações, colocam apelidos pejorativos, difamam, ameaçam, constrangem e menosprezam alguns alunos. Furtam ou roubam dinheiro, lanches e pertences de outros estudantes. Costumam ser populares na escola e estão sempre enturmados. Divertem-se à custa do sofrimento alheio. (SILVA, 2010a, p. II)

Os operadores do Direito, tais como, juiz, promotor, advogado, delegado quando se

depararem com casos de bullying escolar devem se atentar a todas as alternativas para solucionar tal problema. "Não é o princípio da autoridade por si só, que poderá acabar com essas ocorrências num determinado ambiente escolar”. Se o estudante não participar ativamente na solução do problema, a resposta imposta pelo Direito será temporária, não resolvendo o problema das vítimas. (CALHAU, 2006)

Contudo, mesmo existindo programas preventivos na escola e não sendo possível prevenir a ocorrência de casos de Bullying, urgentes medidas devem ser tomadas mesmo que a título repressivo recorrendo o profissional à Lei Penal, referenda-se que seu uso não seja realizada isoladamente.

2.I Consequências físicas e psicológicas do bullying

Os sintomas físicos são os primeiros a dar conta que algo está errado, Silva (2010) assevera que o bullying gera graves e sérios prejuízos à saúde das pessoas e muitas patologias são desenvolvidas e as já existentes são intensificadas devido a tal fenômeno, como transtorno do pânico, fobia escolar, fobia social, Transtorno de Ansiedade Social - TAS, Transtorno de 
Ansiedade Generalizada (TAG), depressão, anorexia, bulimia, Transtorno Obsessivo Compulsivo (TOC), Transtorno do Estresse Pós-Traumático (TEPT). (SILVA, 2oro, p. 37)

Relacionado às dificuldades de ordem emocional, Marchesi (2006, p. 82) ressalta que "as dificuldades emocionais dos alunos podem alterar suas relações sociais com professores e colegas e dificultar seriamente sua aprendizagem. Entre elas se encontram a percepção da falta de afeto, o isolamento social, a tristeza prolongada, o sentir-se marginalizado e maltratado. Ainda a esse respeito o autor mencionado (2006, p. 9o) comenta que os maus tratos entre iguais são uma das condutas violentas que mais danos causa a determinados alunos, principalmente aqueles que são maltratados.

Lopes Neto, que é médico e sócio fundador da Associação Brasileira Multiprofissional de Proteção à Infância e à Adolescência (ABRAPIA), ressalta a importância do acompanhamento por profissionais da saúde para prevenir e combater o bullying escolar:

Os efeitos do Bullying são raramente evidentes, sendo pouco provável que a criança ou adolescente procure o pediatra com a clara compreensão de ser ele autor, ou alvo de bullying. No entanto, é possível identificar os pacientes de risco, aconselhar as famílias, rastrear possíveis alterações psiquiátricas e incentivar a implantação de programas anti-Bullying nas escolas. (NETO,2005, p. I68)

O autor acima mencionado elenca ainda alguns sintomas que são ocasionados pelo bullying:

Enurese noturna, alterações de sono, cefaleia, dor epigástrica, desmaios, vômitos, dores em extremidades, paralisias, hiperventilação, queixas visuais, síndrome do Intestino irritável, anorexia, bulimia, isolamento, tentativas de suicídio, irritabilidade, agressividade, ansiedade, perda de memória, histeria, depressão, pânico, relatos de medo, resistência em ir à escola, demonstrações de tristeza, insegurança por estar na escola, mau rendimento escolar, atos deliberados de autoagressão. (NETO, 2005, p. 169)

Em sua doutrina, Calhau (2009, p. 3-4) descreve alguns casos de Bullying ocorridos em outros países, e que tiveram finais trágicos:

Em 1999, no Instituto Columbine (Colorado, EUA), Eric Harris e Dylan Klebold, vítimas de bullying, entraram na escola e passaram a disparar contra professores e colegas. Após matar doze colegas e um professor, eles se suicidaram. Em 2005, um aluno de 16 anos matou cinco colegas, um professor e um segurança numa escola de Minnesota (EUA). Em 2006, na Alemanha, um ex-aluno abriu fogo numa escola e deixou onze feridos (cometeu suicídio em seguida). Em 2007, um estudante, vítima de bullying, na escola Virginia Tech (EUA) assassinou trinta e duas pessoas e feriu outras quinze. Em novembro de 2007, em Jokela (Finlândia), oito pessoas foram assassinadas por um aluno, que divulgou um vídeo no YouTube, o qual anunciava o massacre. No dia 25 de maio de 2008, um aluno de 22 anos matou nove estudantes e um professor em Kauhajoki (Finlândia). Em seguida se suicidou.

Adota, ainda segundo a autora (2009, p. 3-4), dando conta que em nosso país: 
[...] não são incomuns casos de alunos que são flagrados em escolas com armas de fogo. Em 2003, em Taiúva (SP), um ex-aluno voltou à escola e atirou em seis alunos e numa professora, que sobreviveram ao ataque. Era ex-obeso e vítima de bullying, e após o atentado, cometeu suicídio. Em 2004, em Remanso (BA), um adolescente matou dois e feriu três, após sofrer humilhações (era também vítima de bullying).

Mas as chacinas em escolas no Brasil nunca tiveram em tamanha evidência quando em 20II, Wellington Menezes, 23 anos, entrou em uma escola pública de nome Tasso da Silveira, no Rio de Janeiro, sacou uma arma de fogo, e cometeu uma barbárie conhecida como o "Massacre de Realengo". O assassino deixou uma carta e um vídeo demonstrando uma face cruel de um criminoso insano, contudo os relatos de ex-colegas e familiares demonstram a face de um garoto humilhado e que se sentia abandonado. Com a chegada da Polícia Militar o assassino levou um tiro, e ainda vivo suicidou-se com um tiro na cabeça. (SANTANA, 20I2)

O saldo final foram 12 crianças mortas e outras tantas feridas, sendo que do total dez eram meninas, e com as mesmas características físicas, tipo físico esbelto, cabelos compridos. "Stephany da Silva, I4 anos, teve a arma apontada para sua cabeça, contudo simplesmente ouviu de Wellington 'hoje não é seu dia de morrer', desviando a pistola e atirando na cabeça da garota ao lado" (PRADO; AQUINO, 2oII).

O "Massacre de Realengo" muito tem a ver com o ocorrido em Columbine em 1999 nos Estados Unidos da América e outros tantos semelhantes espalhados pelo mundo, mas um ponto em comum chama a atenção - "os monstros atiradores" e sua vida pregressa.

Em um vídeo Wellington diz que foi vítima de bullying, ressaltando que antes tinha sido "fraco", mas tinha se tornado um "combatente" para defender os que eram incapazes. (BRASIL, 2011)

Um ex-colega que estudou na mesma escola de Wellington disse, "eu me lembro muito, o Wellington era o bundão da turma, era um cara totalmente tranquilo, um bobão. Implicavam bastante com ele, 'zuavam' ele de tudo o que é nome”, contou Bruno, mas depois o jovem ressaltou que "Ele apesar de ser bundão, ele tinha um sorriso assustador." (SANTANA, 2012)

Outro colega, assim relatou que Wellington, “[...] sofria gozações de meninas na época em que estudou no colégio, palco da tragédia. A afirmação é de um ex-colega de Wellington Menezes, que relatou ao portal UOL como as garotas agiam com o assassino': 'As meninas, além de zoarem o jeito dele andar e se vestir, fingiam dar mole pra ele e depois o ridicularizavam.” (SANTANA, 2012)

Duas semanas após a ocorrência do massacre, Wellington foi enterrado em uma cova rasa sem lápide, sem parentes por perto sequer para que seu corpo foi liberado do IML. Não foi enterrado ao lado da mãe adotiva como pediu, estando presente em seu sepultamento somente os coveiros. (SANTANA, 2012). 
2.2 Pesquisas no Brasil sobre bullying

Levantamento realizado pela Associação Brasileira Multiprofissional de Proteção à Infância e Juventude (ABRAPIA), no interregno de 2002 e 2003, que envolveu 5875 estudantes de 5. ${ }^{a}$ a $8 .^{a}$ séries de onze escolas cariocas, tabulou os seguintes dados, que 40,5\% dos alunos pesquisados admitiram ter estado diretamente envolvidos em atos de Bullying naquele período, sendo (16,9\%) vítimas (ou alvos), 10,9\% alvos/autores (ou "bullie/vítimas") e (12,7\%) agressores, ou seja, ou autores de Bullying. (LOPES NETO; SAAVEDRA apud ALBINO; TERENCIO, 2012, p. 5)

Os pesquisadores Albino e Terêncio (2012, p. 5), citam que em 2009 a FIPE (Fundação Instituto de Pesquisas Econômicas) em convênio com o Instituto Nacional de Estudos e Pesquisas Educacionais Anísio Teixeira, pesquisou 18599 pessoas entre estudantes, professores, diretores e demais profissionais da educação, pais ou responsáveis em 59ı escolas de 27 Estados, sendo que os resultados deram conta que o preconceito e a discriminação nas escolas resultam muitas vezes de pessoas que são humilhadas, agredidas ou acusadas injustamente só pelo fato de pertencerem a um grupo social específico. Tal pesquisa demonstra serem os alunos as maiores vítimas e vitimadores de bullying e que:

Entre alunos, os respondentes declaram conhecer mais práticas discriminatórias motivadas pelo fato de serem as vítimas negras (19\%), em seguida por serem pobres $(18,2 \%)$ e, em terceiro lugar, por serem homossexuais $(17,4 \%)$. Já entre professores, as principais vítimas de tais situações são os mais velhos $(8,9 \%)$, os homossexuais $(8,1 \%)$ e as mulheres $(8 \%)$. (ALBINO; TERÊNCIO, 2012, p. 6)

Interessante dado foi tabulado também no ano de 2009, quando da Pesquisa Nacional de

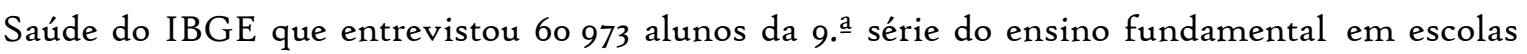
privadas e públicas de todas as capitais do Brasil e do Distrito Federal, sendo que nos trinta dias anteriores à pesquisa, 30,8\% dos alunos entrevistados, de forma ocasional ou frequente sofreram bullying. Tal pesquisa demonstrou também que o Bullying se verifica mais nas escolas privadas $(35,9 \%)$ do que entre as escolas públicas $(29,5 \%)$.(ALBINO; TERÊNCIO, 20I2, p. 6)

Quanto aos locais de ocorrência de Bullying, interessante pesquisa foi feita pela ONG PLAN em 2009, dando conta que a ocorrência de casos tem maior incidência em salas de aula é no pátio, aos olhos muitas vezes cegos de professores e demais responsáveis. (GOMES, L.; SANZOVO, 20II)

No ano de 2010 a investigação "Bullying Escolar no Brasil”, promovida pelo Instituto PLAN (CEATS/FIA) com 5 I68 alunos de 5. $\stackrel{\text { a }}{\text { a }} 8 .^{\text {a }}$ série em 25 escolas públicas e privadas de todas as regiões do Brasil, verificou que:

[...] mais de $34,5 \%$ dos meninos pesquisados foram vítimas de maus tratos ao menos uma vez no ano letivo de 2009, sendo $12,5 \%$ vítimas de bullying, 
caracterizado por agressões com frequência superior a três vezes. Por outro lado, 23,9\% das meninas sofreram maus tratos ao menos uma vez durante o mesmo período, e 7,6\% tornaram-se vítimas de bullying. (ALBINO; TERÊNCIO, 2012, p. 6)

A pesquisa acima referida nos apresenta uma importante informação, de qual é a principal característica da vítima de Bullying que é o aluno “[...] ser diferente dos seus colegas em algum aspecto [...]", e essa diferença pode ser uma característica física que marca, uma deficiência, um status social. (ALBINO; TERÊNCIO, 20I2, p. II).

2.3 Personalidades públicas que foram vítimas de bullying

Semelhante a muitos anônimos que até hoje sofrem com o Bullying, algumas pessoas famosas também sofreram de tal mal, contudo conseguiram superar o sofrimento e alcançarem a fama. O nadador americano e medalhista em olimpíadas Michael Phelps:

[...] encontrou na natação uma forma de se refugiar das constantes brigas de seus pais, além de poder direcionar seu foco. Debbie, a mãe do nadador, declarou à revista US Magazine que o bullying e as adversidades fizeram com que ele se fortalecesse e batalhasse mais. (SILVA, A., apud PEREIRA, [d.a. 20II], p. 6).

Tom Cruise, ator americano também sofreu muito, fato observado nos sintomas que sentia:

Cruise, considerado baixo para sua idade e disléxico, era um alvo fácil de ataques de bullying. Por diversas vezes, na escola, foi intimidado e empurrado por valentões bem maiores que ele. Isso fazia seu coração disparar e tinha vontade de vomitar. Sentia-se excluído, sozinho e ansiava em ser aceito. "Eu não tinha um amigo mais próximo, alguém com quem eu pudesse me abrir e em quem pudesse confiar [...]" (SILVA A., apud PEREIRA, [d.a. 20II], p. 7).

O cineasta americano Steven Spielberg, criador de filmes fantásticos como Jornada nas Estrela e “ET", deu conta que:

Os anos em que estudou em Saratoga High School, subúrbio da cidade de São Francisco, foram considerados por Steven como os piores de sua existência. No colégio, havia vários alunos que odiavam judeus, e ele frequentemente era hostilizado pelo grupo. Quando Spielberg passava pelos corredores, os colegas de classe, muitas vezes, imitavam o som de um espirro, utilizando a expressão "haw-jew", numa demonstração clara de alergia e aversão ao judeu. Os assédios, invariavelmente, continuavam após as aulas. (SILVA, A., apud PEREIRA, [d.a. 2011], p. 7).

Famosos ou anônimos, alunos de escolas públicas ou particulares, ricos e pobres, sofrem cotidianamente com o bullying, e o relato dos famosos acima referenciados demonstram visivelmente que é possível vencer tal mal. 
3 Responsabilização de menores de idade em casos de bullying escolar- atos infracionais e medidas socioeducativas

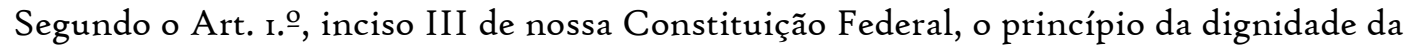
pessoa humana é um dos fundamentos da República Federativa do Brasil, que é constituída em Estado Democrático de Direito, sendo que segundo Nery Jr. e Nery (2009, p. 15I), "esse princípio, estatuído na norma comentada, tem a finalidade de impedir que o ser humano seja utilizado como objeto nos procedimentos estatais”.

$\mathrm{Na}$ esteira do arrazoado, considerando o princípio da dignidade da pessoa humana e o fato do menor estar em desenvolvimento, e principalmente quanto a maior incidência do Bullying ocorrer entre menores de idade, nossa Constituição Federal é clara ao estabelecer que os menores de dezoito anos são considerados inimputáveis, verbis: "Art. 228. São penalmente inimputáveis os menores de dezoito anos, sujeitos às normas da legislação especial”.

No que reza a nossa Constituição, por conta de sua condição de pessoa em desenvolvimento os:

[...] adolescentes são e devem seguir sendo inimputáveis penalmente, quer dizer, não devem estar submetidos nem ao processo, nem às sanções dos adultos e, sobretudo, jamais e por nenhum motivo devem estar nas mesmas instituições que os adultos. No entanto, os adolescentes são e devem seguir sendo responsáveis por seus atos (típicos, antijurídicos e culpáveis). Não é possível nem conveniente inventar aforismos difusos, tais como uma suposta responsabilidade social somente aparentemente alternativa à responsabilidade penal. Contribuir com a criação de qualquer tipo de imagem que associe adolescência com impunidade (de fato ou de direito) é um desserviço que se faz aos adolescentes, assim como, objetivamente, uma contribuição irresponsável às múltiplas formas de justiça com as próprias mãos, com os quais o Brasil desgraçadamente possui uma ampla experiência. A responsabilidade - neste caso penal - dos adolescentes é um componente central de seu direito a uma plena cidadania. Pretender construir cidadania sem responsabilidade constitui um contrassenso, produto da ingenuidade ou da incompetência. (GARCIA MENDEZ apud TEJADAS, 2007, p. 6I)

A Lei n. 8 o69 de 13 de julho de 1990- Estatuto da Criança e do Adolescente esclarece em seu art. 2.o que "considera-se criança, para os efeitos desta Lei, a pessoa até doze anos de idade incompletos, e adolescentes aquela entre doze e dezoito anos de idade".

Giza perlustrar que o bullying em muitas oportunidades é praticado por menores de idade (criança/adolescente) em face deles próprios ou contra um maior de idade, e por conta da característica especial da menoridade penal, a forma processual de apuração e de aplicação de medidas protetivas ou socioeducativas é disciplinada pelo Estatuto da Criança e do AdolescenteECA, sendo que o menor responderá sim pelos ilícitos penais praticados na condição de "ato infracional análogo" aos crimes praticados pelos maiores de idade, no que as "medidas protetivas" estão previstas no Art. Ior e as "socioeducativas" no Art. II2 do Estatuto em comento, 
que podem ir desde advertência até três anos de internação em instituição própria, e que permite a ressocialização, dependendo da idade e da gravidade do ato infracional praticado. Portanto, salientamos que é uma visão equivocada aquela presente no senso comum de que o Estatuto de Criança e do Adolescente somente prevê direitos aos menores de idade.

Muitos atos infracionais que sua origem em atos praticados e tidos como bullying, como a injúria, ameaça, difamação, lesão corporal, furtos, roubos, racismo entre outros, são passíveis de serem apreciados por parte do Poder Judiciário, tendo em caso específico o Tribunal de Justiça do Distrito Federal apreciado um recurso e assim decidido:

PENAL E PROCESSUAL PENAL. TENTATIVA DE ROUBO E POSTERIOR EXTORSÃO CONTINUADA. CREDIBILIDADE DA PALAVRA DA VÍTIMA. AFASTADA A CONTINUIDADE DELITIVA. SENTENÇA MANTIDA

A vítima, um garoto com apenas catorze anos, foi submetida ao que a Associação Brasileira Multiprofissional de Proteção à Infância e à Adolescência denomina de bullying. Seu sofrimento começou a partir de uma tentativa frustrada de roubo, quando gritou por socorro e o réu se afastou, temendo a reação dos transeuntes. Desde então, passou a importuná-la no caminho da escola, exigindo-lhe dinheiro. As ameaças de morte a si e aos familiares levavam-na a entregar ao extorsionário todo o dinheiro que ganhava dos pais, passando também a vender seus pertences de modo a atender a essas exigências. Diante do clima de terror que lhe infundia o algoz, desenvolveu grave distúrbio psicológico que prejudicaram seu desempenho escolar e a obrigaram a tratamento especializado, passando a ser medicada com psicotrópicos. (Apelação Criminal n. 2004091 olı 545-4APR - DF, i3.10.2008)

Mas por conta da peculiaridade da ocorrência do Bullying no seio escolar, onde inúmeras variantes devem ser consideradas na sua apreciação, cremos que agir preventivamente é o melhor caminho, e assim agindo, os estabelecimentos de ensino estarão procedendo conforme reza o Art. 70 do Estatuto da Criança e do Adolescente que institui: "É dever de todos prevenir a ocorrência de ameaça ou violação dos direitos da criança e do adolescente". Contudo, sendo constatado a ocorrência do Bullying, que se adéque a tipos penais e por conta da lei especial, considerados como ato infracional, depreende-se do mesmo Estatuto em seu Art. 245, o dever de comunicação às autoridades competentes, nestes termos:

Art. 245. Deixar o médico, professor ou responsável por estabelecimento de atenção à saúde e de ensino fundamental, pré-escola ou creche, de comunicar à autoridade competente os casos de que tenha conhecimento, envolvendo suspeita ou confirmação de maus-tratos contra criança ou adolescente.

Em sede do arrazoado, cumpre-nos trazer a lume o Art. 13 do Código Penal (Decreto-Lei n. -2 848, de 7 de setembro de 1940), in verbis:

Art. 13 - O resultado, de que depende a existência do crime, somente é imputável a quem lhe deu causa. Considera-se causa a ação ou omissão sem a qual o resultado não teria ocorrido.

$[\ldots]$ 
$\S 2^{\mathrm{O}}$ - A omissão é penalmente relevante quando o omitente devia e podia agir para evitar o resultado. $O$ dever de agir incumbe a quem:

a) tenha por lei obrigação de cuidado, proteção ou vigilância.

Por conta de uma interpretação literal do artigo acima, o professor o pedagogo ou o diretor do estabelecimento de ensino, podem ser processados penalmente, quando tendo conhecimento de casos de Bullying, em que vítima foi ferida (o que não é raro), em oportunidade que deveriam agir para evitar o mal, e “podendo” não o fizeram. É claro que o professor não é preparado com técnicas policiais para enfrentar um aluno armado, porém, as pequenas e constantes agressões físicas podem e dever ser evitadas por aqueles que se encontram imbuídos do dever de cuidado.

\section{I Agentes que compõe o bullying}

Um fator de grande relevância a ser considerado sobre o Bullying, é quanto a análise dos seus agentes (meninas ou meninos), no que Fante e Pedra (2008, p. 64) ressaltam que sua maior incidência é entre meninos:

No passado, acreditava-se que esse tipo de comportamento era próprio de menino, porém, com os avanços das pesquisas, constatou-se ser comum também entre meninas. Enquanto maioria dos meninos utiliza, comumente, maus tratos físicos e verbais, as meninas se valem mais da maledicência, fofoca, difamação, exclusão e manipulação para provocar sofrimento psicológico nas vítimas. Os ataques das meninas, ao contrário dos ataques dos meninos, acontecem dentro de um círculo restrito de amizades, o que torna a agressão mais difícil de identificar, reforçando o dano causado a sua vítima.

Existe uma variação de idade entre agressores e vítimas, assim nos ensinam Fante e Pedra (2008, p. 47):

[...] pesquisas demonstram que a média de idade de maior incidência entre os agressores situa-se na casa de 13 aos 14 anos, enquanto as vítimas possuem a média de II anos, fato que comprova a teoria de que os papéis dos protagonistas se intensificam conforme aumenta o grau de escolaridade.

Ainda refletindo sobre qual o sexo que ocorre maior incidência do Bullying, o CNJ em sua cartilha esclarece que:

Estudos revelam um pequeno predomínio dos meninos sobre as meninas. No entanto, por serem mais agressivos e utilizarem a força física, as atitudes dos meninos são mais visíveis. Já as meninas costumam praticar bullying mais na base de intrigas, fofocas e isolamento das colegas. Podem, com isso, passar despercebidas, tanto na escola quanto no ambiente doméstico. (SILVA, A., 2010a, p. 7) 
3.2 Direito Penal como última ratio

O ser humano não é uma ilha, ou seja, não vive senão em sociedade, contudo a vida em comum depende da existência de regras presentes desde as mais primitivas organizações sociais. Contudo, o homem possuidor do livre arbítrio sempre violou as regras de convivência. Com a evolução social o homem criou um ente abstrato o Estado, para o qual transferiu poderes, como o de criar regras formais e de punir, não cabendo mais ao homem a vingança privada. Hoje não cabe ao cidadão, por si, buscar a vingança quando ferido em seus direitos, por conta do poder que concedeu ao Estado, e em vista do contrato social deve buscar no Estado o meio para ser garantido o que lhe foi tomado à força, não só quanto a bens materiais, mas como os imateriais.

Aquelas condutas humanas que normalmente causam maior repulsa no meio social apresentam sanções de variadas formas, como as multas pecuniárias, obrigações de fazer, e as restrições à liberdade, dentre outras. O Direito Penal se preocupa com apenas uma parte das condutas praticadas pelo homem, e só aquelas condutas humanas consideradas mais reprováveis devem ser criminalizadas.

E nesse sentido as condutas humanas danosas promovidas pelos bullies, ferem a sociedade de forma atroz violando:

[...] os direitos de suas vítimas. Diversos direitos tutelados pela Constituição Federal e pelo Estatuto da Criança e do Adolescente são atingidos com essa prática lesiva. Em especial, violam-se também os direitos da personalidade como a intimidade e a honra. Os direitos personalíssimos existem desde o nascimento, permanecem por toda a vida e ninguém deve infringi-los. (GONÇALVES apud GOMES, M., 20II)

$\mathrm{Na}$ esteira do presente trabalho, não podemos deixar de citar a doutrina de Capez (2005, p. I) o qual conceitua Direito Penal como sendo:

[...] o seguimento do ordenamento jurídico que detém a função de selecionar os comportamentos humanos mais graves e perniciosos à coletividade, capazes de colocar em risco valores fundamentais para a convivência social, e descrevêlos como infrações penais, culminando-lhes, em consequência, as respectivas sanções, além de estabelecer todas as regras complementares e gerais necessárias à sua correta e justa aplicação.

Adentrando ao estudo do Direito Penal, não é pacífico entre os doutrinadores a concordância em judicializar o Bullying, a saber:

\section{$[\ldots]$}

A socióloga Miriam Abramovay, coordenadora de políticas públicas para juventude da Faculdade Latino-americana de Ciências Sociais (Flacso), concorda e diz que há o risco de "judicializar" problemas que devem ser resolvidos no âmbito da escola.

[...]

O advogado Danilo Sahione, especialista em direito educacional e com experiência em casos do tipo, é outro que não vê muita utilidade prática para a tipificação do crime de bullying. Para ele, a questão é muito mais complexa para ser definida de uma forma que ele considera simplista. 
$[\ldots]$

Já o advogado André Pedrosa, especialista em direito processual civil e com experiência em casos de bullying que foram levados à Justiça, acredita que a tipificação do crime de bullying é benéfica pelo efeito psicológico e moral que pode vir a ter, ao mostrar que essa é uma questão que pretende ser levada a sério pela legislação brasileira. (CASES; JANSEN, 20I2)

No site da cidade de São Carlos (2012) o estudante de física da Universidade de São Paulo (USP) Gustavo Gregório, de 18 anos, que na escola sofreu bullying desabafa que:

Quando tinha I2 anos, ele foi perseguido por colegas de classe por tirar boas notas. O jovem acredita que o bullying só será combatido quando os agressores forem punidos com rigor. "Não é difícil reconhecer o bullying. É um monte de gente em cima de uma pessoa só, todo dia. Começa com tapa na cabeça, nas costas e depois vira soco. Começam a te agredir cada vez mais. Eu sou a favor de punição para quem comete o bullying", disse.

O Direito Penal sendo o meio mais gravoso para se promover o controle social deve ser utilizado em último caso (ultima ratio). Nesse sentido Mcneil e Dunbar Jr. apud Cabral (20II), dão conta da existência de um trabalho que relata sobre políticas de "tolerância zero" nas escolas são ineficientes, pois, existe um enorme sentimento de insegurança no meio escolar. Afirmam ainda que tais políticas tiveram origem nos anos 90 para combater a violência escolar em Nova Iorque, e acabaram demonstrando serem ineficientes, pois, esqueceram o objetivo principal da escola que é garantir educação de alta qualidade num ambiente seguro e que estimule o crescimento acadêmico, o que para ocorrer é necessário a existência de justiça e ponderação. Por

fim a ansiedade gerada nos alunos com a política da tolerância zero gera um ambiente escolar tenso e inadequado ao aprendizado.

Valente (2012) escrevendo sobre a política de Tolerância Zero no ambiente escolar empregada nos Estados Unidos da América, esclarece que "a tolerância zero contra a violência nas escolas $[\ldots]$, naquele país estava $[\ldots]$ envolvida em controvérsias e críticas, com a punição dura de crianças e adolescentes em razão de delitos banais.”

Uma política radical não é o melhor caminho para o combate ao Bullying, pois, não se baseia na justiça, no que é razoável. Sem tais atributos o radicalismo da tolerância zero acaba se transformando numa verdadeira política de "inteligência zero". (RICHARDSON, apud CABRAL, 20II)

3.3 Direito Penal e sua aplicação multidisciplinar aos casos de bullying

Existem algumas iniciativas por parte de legisladores estaduais para se combater a prática do Bullying nas escolas. Por exemplo, o Estado de Santa Catarina aprovou a Lei Estadual n.o I4 651, de 12 de janeiro de 2009, que propõe a instituição de um "Programa de Combate ao Bullying", de ação interdisciplinar e de participação comunitária, nas escolas públicas e privadas 
do estado. Nesse mesmo caminho seguiu o Distrito Federal com a Lei n.o 4 837, de 22 de maio de 2012 que "dispõe sobre a instituição da política de conscientização, prevenção e combate ao bullying nos estabelecimentos da rede pública" e o Estado do Paraná publicando a Lei n.ํำ 1735 de Io de outubro de 2012, a qual "institui o Programa de Combate ao Bullying, de ação interdisciplinar e de participação comunitária, nas Escolas Públicas e Privadas”.

As leis citadas apresentam planos de ação preventiva contra o bullying estimulando o diálogo, contudo devido ao fato de serem leis Estaduais não apresentam sanções de ordem penal, pois, somente à União cabe legislar sobre Direito Penal (Art. 22, I da CF/88), e até a presente data não existe uma legislação abrangente, ou seja, de ordem Federal sobre o bullying, contudo existe um Projeto de Lei n. ${ }^{-}$1785/II tramitando no congresso a espera de aprovação.

Cremos que o diálogo entre os membros do organismo escolar é uma ótima medida, contudo, não podemos ficar indiferentes quanto ao fato do Direito Penal ser uma das armas a serem utilizadas na guerra contra o bullying, dando conhecimento aos agressores, quer sejam menores de idade ou não, que arcarão com consequências de ordem judicial junto ao Poder Judiciário acaso pratiquem bullying. Contudo, aplicar uma punição ao bullie de forma isolada não resolverá o problema, assim, é o entendimento de Salgado (2010).

As políticas de bullying terão poucos efeitos quando se procurar apenas sancionar o buller. Essa é apenas uma das práticas a serem adotadas, mas não pode ser a única. $O$ comportamento do buller é terrível, mas ele é reflexo de uma série de valores e atitudes disseminados na sociedade moderna. Apenas práticas conjuntas podem trazer a diminuição do bullying. A política anti-bullying deve também prestar atenção nas testemunhas/participantes da ação de bullying, estimular as denúncias da prática, amparar vítimas e testemunhas, informar da prática e das suas consequências aos pais/professores/população, promover a socialização da criança na escola com difusão da importância de se viver em uma sociedade plural e democrática, difundir que a discriminação/racismo/desrespeito às pessoas é uma atitude nefasta socialmente e tem de ser evitada, valorizar os jovens ouvindo-os e criando esferas de verdadeira integração social, etc. O fenômeno do bullying é complexo e para ser coibido tem de contar com todas as esferas da sociedade.

A norma positivada não conseguirá nunca abranger todo comportamento e reação promovida pelo ser humano, e por esse e outros motivos a realização de um trabalho preventivo é de suma importância. 
3.4 Tipos penais que se adéquam a casos de bullying e a desnecessidade de tipo penal específico

Como figura típica penal incriminadora o Bullying não existe na seara do Direito Penal, contudo cada núcleo verbal de determinada conduta que possa ser praticada pelo bullie deve ser apreciada individualmente, objetivando fixar a legal adequação e consequente responsabilização penal com o final de um devido processo legal.

Segundo Gomes, L., e Sanzovo (2012), a Comissão formada por jurista para modificação do atual Código Penal, incluiu o bullying como um novo tipo penal, por crerem que sua criminalização trará maior seriedade aos fatos que ocorrerem cotidianamente em nossas escolas. A criminalização do bullying, está prevista na modificação do Código Penal Brasileiro, tendo o nomem iuris "intimidação vexatória", sendo acrescentado em um segundo parágrafo do art. I47 do Código Penal, in verbis:

Art. 147 - Ameaçar alguém, por palavra, escrito ou gesto, ou qualquer outro meio simbólico, de causar-lhe mal injusto e grave: Pena - prisão de seis meses a dois anos.

$\$ 2^{\circ}$ Intimidar, constranger, ameaçar, assediar sexualmente, ofender, castigar, agredir, segregar a criança ou o adolescente, de forma intencional e reiterada, direta ou indiretamente, por qualquer meio, valendo-se de pretensa situação de superioridade e causando sofrimento físico, psicológico ou dano patrimonial. Pena - prisão de um a quatro anos.

Muitos creem ser necessária a criminalização do bullying para que um resultado efetivo ocorra na sua prevenção e em especial para combatê-lo, contudo, outra corrente diametralmente oposta defende ser desnecessária tal tipificação, pois devido à prática repetida dos atos de bullying, certamente será encontrado adequação típica na legislação penal já existente em nosso ordenamento.

Seguindo na linha da segunda corrente acima exposta, inúmeras condutas praticadas pelo bullie podem se adequar tranquilamente aos tipos penais já existentes em nosso Código Penal e em determinados casos com penas graves, como no caso do:

Art. 129 (Lesão Corporal), prática de violência que deixe na vítima lesões corporais como ferir o colega com estilete, socos e chutes;

Art. I40, §3을 do CPB (Injúria Qualificada), no caso de xingamentos devido a raça, etnia, opção sexual da vítima;

Art. 146 do CPB (Constrangimento Ilegal), por meio de violência física ou grave ameaça não permitir que a vítima passe por determinado local ou obrigála a suportar determinadas condutas como trotes;

Art. 147 do CPB (Ameaça), ameaçar a vítima de morte ou de causar-lhe mal injusto por meio de palavras, escritos ou gestos;

Art. 148 do CPB (Cárcere Privado), quando a vítima for mantida enclausurada em determinado local como sala de aula ou banheiro após o fechamento da escola;

Art. 155 (Furto), no caso de subtrair dada vítima seu dinheiro para o lanche ou o tênis a mochila, enfim qualquer bem móvel;

Art. 157 (Roubo) quando utilização de violência ou grave ameaça para subtração de bens móveis da vítima; 
Art. 163 do CPB (Dano), aplicável aos casos de dano ao patrimônio da vítima como destruição de celular, mochila, contudo a título somente de dolo, pois, não existe dano culposo;

Art. 213 do CPB (Estupro) o qual para que assim seja considerado não existe a necessidade da conjunção carnal, tipifica-se tal crime mesmo o ato violento ao pudor como apalpações lascivas.

Enfim podemos citar ainda dentre a Legislação Especial, a Lei n. 7 716, de os de janeiro de 1989, que define os crimes resultantes de preconceitos de raça ou de cor, sendo que em tal lei existem inúmeros verbos, contudo citamos o Art. 20, textualmente:

Art. 20 - Praticar, induzir ou incitar a discriminação, ou preconceito de raça, cor, etnia, religião ou procedência nacional. Pena: reclusão de I (um) a 3 (três) anos e multa.

§ Io - Fabricar, comercializar, distribuir ou veicular símbolos, emblemas, ornamentos, distintivos ou propaganda que utilizem a cruz suástica ou gamada, para fins de divulgação do nazismo. Pena: reclusão de 2 (dois) a 5 (cinco) anos e multa.

3.5 Prevenção como medida eficaz

Como assevera Gomes L., e Sanzovo (2012), a tipificação criminal do Bullying não é suficiente para acabar com tal mal, mas deve ocorrer de forma interdisciplinar, ou seja, várias disciplinas devem trabalhar em comum, como a pedagogia a psicologia e o próprio Direito, pois, a simples criminalização isolada no contexto geral atinge somente as consequências e não a causa do Bullying.

Conforme bem ensina Calhau (2006), atuar preventivamente em casos de Bullying escolar é a melhor saída, as práticas violentas devem ser coibidas, propagando em vez de violência a tolerância e a solidariedade. Ressalta o autor que devemos olvidar esforços no sentido de diagnosticar na realidade escolar local a ocorrência do bullying, promovendo o esclarecimento que em muitos casos facilita o controle, e isso só ocorre com um “diálogo franco" entre os envolvidos.

Nesse sentido medidas práticas podem ser tomadas no ambiente escolar como:

[...] aumentar a supervisão na hora do recreio e intervalo; evitar em sala de aula menosprezo, apelidos, ou rejeição de alunos por qualquer que seja o motivo. Também pode-se promover debates sobre as várias formas de violência, respeito mútuo e a afetividade, tendo como foco as relações humanas. (SILVA, 2006, p. 02)

O Bullying escolar, atualmente pode ser considerado um problema de saúde pública, razão pela qual, tanto os professores quanto as demais pessoas ligadas ao espaço escolar devem melhor observar, atentando-se para a ocorrência de violências, neutralizando os agressores e assegurando às vítimas assistências psicológica e transformando os espectadores em aliados. (SILVA, 2006) 
3.6 O bullying e a linguagem do adolescente

A socialização é o processo pelo qual os indivíduos adquirem padrões de comportamento que são valorizados pelo grupo e adequados para sua adaptação ao ambiente social. Dessa maneira, se faz necessário entender como dá a construção da moral na criança, visto que, a moral acha-se intimamente relacionada com os atos conscientes e voluntários dos sujeitos que afetam outros sujeitos, determinados grupos sociais, ou a sociedade em seu conjunto. (GIANCATERINO, 2008)

Há de se notar que os problemas disciplinares ganham em dimensão e em quantidade no dia-a-dia das escolas, portanto, discutir o tema moralidade implica em uma análise muito precisa das relações que o sujeito desenvolve com outras pessoas, uma vez que, trata-se de um processo no qual a definição de regras é o limite caracterizado pela necessidade de manter o respeito como conceito fundamental.

Assim sendo, na perspectiva piagetiana, a formação moral e intelectual do indivíduo deve consistir em alvo de preocupação e de grande interesse por parte dos adultos que convivem com a criança. (BALESTRA, 2007).

As raízes do vocábulo 'moral' derivam do latim mos, morus ou mores, no sentido de um conjunto de normas ou regras adquiridas por hábito, reafirmando os ideais piagetianos.

Para Piaget (citado por Balestra, 2007) os sentimentos ou tendências afetivas são manifestados pela criança já no início da sua constituição mental. Desde cedo ela manifesta necessidade de amor, exteriorizando-a por meio de várias maneiras; o medo também está permanentemente presente nas suas relações com o mundo.

Ainda de acordo com Piaget, a criança irá passar por três etapas na construção do juízo moral. A Anomia, predominante até os cinco anos ou seis anos, as regras coletivas ainda não são seguidas pela criança durante essa fase (anomia), porque ela tende à satisfação de suas fantasias simbólicas, concentrando-se apenas em suas atividades motoras.

A Heteronomia ocorre normalmente até os nove ou dez anos, a criança submete-se às regras impostas pelo meio, acatando com total obediência às ordens vindas das outras pessoas. Vê-se esse processo como responsável pela dificuldade apresentada pela criança em conceber as regras como um contrato firmado entre os jogadores, uma vez que ela as vê e as obedece como algo sagrado e imposto pela tradição.

$\mathrm{Na}$ Autonomia, alcançável por volta dos onze ou doze anos, pode ser percebida uma inversão total na conduta da criança, tanto no plano da consciência quanto no da prática; as regras, aqui não são mais consideradas sagradas e imutáveis; o acordo mútuo (democracia) pode 
levar a alterações, quando o objetivo é o bem coletivo. É nessa fase do juízo moral que a coação (respeito unilateral) cede terreno para a cooperação (respeito recíproco). (BALESTRA, 2007)

Compreende-se, então, que o estabelecimento do respeito mútuo requer reciprocidade na troca de opiniões entre as pessoas; esse procedimento representa um poderoso método educativo por permitir que os fatores determinantes das ações que estão em julgamento, sejam elas, boas ou más, possam ser explicitados, discutidos e avaliados no ponto de vista, tanto da criança quanto do adulto.

No entanto, a moral é passível de ser conquistada pela educação; admite-se que os jogos coletivos, apoiados em regras, são suas ferramentas essenciais, desenvolvendo suas pesquisas, inclusive, no antigo jogo de bolinhas de gude para os meninos e o de amarelinha para as meninas.

$\mathrm{Na}$ visão piagetiana, a criança constrói o conhecimento e o julgamento moral nas relações que estabelece com os outros; os objetivos educacionais, na escola ou na família, devem priorizar esse aspecto do desenvolvimento infantil. Por isso, a criança deve ter contato com situações que promovam a construção do conhecimento moral, que possam possibilitar o exercício do julgamento moral, para poder solidificar o comportamento moral. (BALESTRA, 2007)

De certa forma, a moralidade obriga o homem a adquirir uma postura a respeito da sua ação, conduzindo-o à reflexão, à definição da personalidade de forma a manter o equilíbrio individual e coletivo. É necessário refletir antes da ação propriamente dita, de modo que esta seja o resultado conveniente à situação em que o indivíduo está inserido.

Percebe-se que será por meio da linguagem falada que o adolescente expressará o que pensa, no entanto, será pela linguagem escrita é que ele exporá seus sentimentos, seus problemas e suas angústias.

Contudo, para que o adolescente possa se expressar há de se saber ouvir. A adolescência é marcada pela agressividade, rebeldia e a falta de interesse pelas aulas. O jovem entre os onze e treze anos está passando por um período de instabilidade psicológica natural, em que ele revive conflitos típicos da infância (Nádia Bossa, citada por CAVALCANTE, 2004)

Isso significa que, quando criança de dois ou três anos, essa percebe sua fragilidade, grita, teima, testa os adultos. $\mathrm{O}$ adolescente faz o mesmo, ele testa limites dos adultos numa tentativa de estabelecer novos parâmetros de poder sobre sua realidade.

No entanto, há de se ficar atento para essas atitudes inadequadas, uma vez que, agressividade ou problemas de socialização podem ter causas mais sérias, com as quais o adolescente não sabe lidar. Por isso, é importante que o professor conheça o histórico familiar do adolescente para tomar as providências e ações acerca dessa criança. 
${ }_{4}$ Considerações finais

Com o desenvolvimento do presente trabalho alcançou-se o objetivo proposto de proporcionar a comunidade escolar e aos operadores do Direito, ferramentas no sentido de que possam adequar juridicamente casos de Bullying sob a luz da ciência educacional e do Direito, tomando medidas legais na esfera do Direito Penal.

Impressionante constatar que os alunos autores de bullying não se dão conta de que há algo errado acontecendo com eles, ao fazerem as ditas brincadeiras, julgam que estão fazendo algo normal, sem restrições e que não precisa haver punição.

Contudo, entre os alvos impera o medo e a vergonha por serem tão frágeis e aceitar as brincadeiras que os colegas de classe fazem, para as testemunhas só resta presenciar e esperar o professor tomar alguma atitude em relação ao autor.

Quanto ao problema apresentado, a questão colocada foi como se processa a responsabilização penal entre alunos maiores ou menores de idade, por conta de atos por eles praticados que se enquadrem como casos de Bullying, ante a não existência de um tipo penal incriminador em nosso ordenamento.

Em sede de hipótese delimitada na presente pesquisa comprovou-se a possibilidade de aplicação do Direito Penal aos casos de Bullying escolar que ocorrem na atualidade no Brasil, e que o simples fato de inexistir uma legislação específica não é impedimento para que bullies sofram sanções penais justas quer sendo maiores ou menores de idade.

Os freios legais existentes em nosso ordenamento jurídico não se encontram ultrapassados a não permitirem sua utilização frente a casos de Bullying escolar, cremos ser necessário a utilização da legislação existente com inteligência, interpretando a norma já existente frente ao contexto social atual, sem que seja necessária uma legislação para se promover o enfrentamento do Bullying na seara do Direito Penal, contudo, uma legislação especifica seria bem-vinda, posto que demonstraria que o legislador se encontra realmente preocupado com tal mal.

Felizmente o Poder Judiciário demonstra que se encontra atento e não ignorando os fatos graves que tem ocorrido no meio social, em especial por conta de jurisprudências que tem formado, demonstrando claramente que valores positivos como a tolerância e a solidariedade ainda são bens jurídicos de primeira grandeza.

O legislador Estadual corrobora em vários estados uma preocupação com os casos de Bullying escolar, tendo na competência lhe concedida pela Constituição Federal, promulgado leis que apresentam ações eminentemente "preventivas" de ação interdisciplinar e de participação comunitária. 
A escola tem a obrigação de proporcionar aos alunos condições adequadas para que desenvolvam intelectualmente seus conhecimentos, de forma que o fato de ir à escola seja um prazer, portanto, a equipe pedagógica deve estar atenta aos casos de Bullying, dando conta de estratégias que possibilitem seu combate de forma preventiva, e por derradeiro tentando dissuadi-lo utilizando a legislação penal. Caso contrário os alunos levarão para o resto da vida males irreversíveis provocadas pelas humilhações, rejeições e gozações.

O Poder Legislativo Federal tem uma tarefa de suma importância que é a de elaborar uma Lei Ordinária, criando um tipo penal específico para que ocorra uma perfeita subsunção do fato ao tipo, com isso visando maior efetividade à punição dos bullies.

Apesar da demonstração da preocupação por parte do CNJ sobre o Bullying escolar, inclusive com lançamento de uma cartilha sobre o tema, efetivamente a jurisprudência penal é parca frente a um tema tão importante à sociedade.

Percebe-se, infelizmente, que em pleno século XXI, os valores e as regras têm sido abandonados, tanto pais quanto filhos esqueceram que os bons modos nunca saem de moda, que as regras existem para serem cumpridas, e que garantirão uma boa convivência entre seus pares.

Para os professores cabem a função de orientar os alunos a seguirem caminhos que não os farão sofrer posteriormente, entretanto, não é papel do professor ensinar os alunos regras que deveriam ser transmitidas pela família, por isso deve pensar atitudes que levem os alunos à aprendizagem significativa e proporcione momentos de reflexão e orientação aos alunos sobre a vida e o que pretendem dela.

$\mathrm{E}$ ao atuar junto à equipe de coordenadores sugerindo atividades que não fazem parte do currículo, mas que trarão algum benefício aos alunos, o professor proporcionará aos alunos, situações para que eles possam conviver na comunidade que atuam de maneira responsável e feliz.

Pretendemos que além da comunidade acadêmica, os operadores do Direito, e aqueles que compõem o ambiente escolar como professores, pais, pedagogos, ou a quem for apresentado o presente trabalho possa enriquecer seus conhecimentos quanto a tão importante tema.

\section{REFERÊNCIAS}

ABRAMOVAY, Miriam; RUA, Maria das Graças. Violência nas escolas. Brasília. DF: UNESCO, Instituto Ayrton Senna; UNAIDS; Banco Mundial; USAID; Fundação For; CONSED; UNDIME, 2002.

ALBINO, Priscila Linhares; TERÊNCIO, Marlos Gonçalves. Considerações sobre o fenômeno do bullying: Do conceito ao combate e à prevenção. Revista Eletrônica do CEAF. Porto Alegre, RS: Ministério Público do Estado do RS. Vol. I, n.2, fev/maio 2012. 
ARRIETA, Gricelda Azevedo. A violência na escola: a violência na contemporaneidade e seus reflexos na escola. Canoas: Ulbra, 2000.

BALESTRA, Maria Marta M. A psicopedagogia em Piaget: uma ponte para a educação da liberdade. Curitiba, Ibpex, 2007.

BARROS, Aidil J. da Silveira; LEHFELD, Neide Aparecida de Souza. Fundamentos de Metodologia: um guia para a iniciação científica. 2. ed. São Paulo: Makron Books, 2000.

BITTAR, Eduardo Carlos Bianca. Metodologia da pesquisa jurídica: teoria e prática da monografia para os cursos de direito. 5. ed. São Paulo: Saraiva, 2007.

BRASIL. Sandra. O retrato da mente de um monstro. In: Veja. 2213, ano 44, no 16,20 abr. 2011.

BRASIL. Constituição (1988). Constituição da República Federativa do Brasil. Disponível em: 〈http://www.planalto.gov.br/ccivil_03/Constituicao/Constitui\%C3\% A7ao.htm〉. Acesso em: or ago. 2020 .

BRASIL. (Código Penal) Decreto-Lei no 2.848, de 7 de setembro de 1940. Disponível em: 〈http://www.planalto.gov.br/ccivil_03/Decreto-Lei/Del2848.htm>Acesso em: or ago. 2020.

BRASIL. Lei no 8.069 de 13 de julho de 1990. Dispõe sobre o Estatuto da Criança e do Adolescente e dá outras providências Disponível em: 〈http://www.planalto.gov.br/ccivil_03/leis/L8o69.htm〉Acesso em: 04 ago. 2020.

BRASIL. Lei $\mathrm{n}^{\mathrm{0}}$ 7.716, de o5 de janeiro de 1989. Define os crimes resultantes de preconceito de raça ou de cor. Disponível em: <http://www.planalto.gov.br/ccivil_

03/leis/L7716.htm>Acesso em: 04 ago. 2020.

CABRAL, Bruno Fontenele. "Zero tolerance". Efetividade da aplicação de políticas de tolerância zero nas escolas norte-americanas. Jus Navigandi, Teresina, ano I6, n. 275I, I2 jan. 2011. Disponível em: $\langle$ http://jus.com.br/revista/texto/r8252/zero-tolerance $>$. Acesso em: 05 ago. 2020.

CAPEZ, Fernando. Curso de Direito Penal, parte geral. vol. I, [ S.I.]: Saraiva, 2005.

CALHAU, Lélio Braga. Bullying: O que você precisa saber: identificação, prevenção e repressão. Niterói, RJ: Impetus, 2009.

Impetus, 2010.

O que você precisa saber: identificação, prevenção e repressão. 2 ed. Niterói, RJ: Mediação de conflitos: o papel do ministério público face a indisciplina no contexto escolar. 2I maio 2012. Disponível em: $\mathrm{http}: / / \mathrm{www}$.leliobragacalhau.com.br/mediacao-deconflitos-o-papel-do-ministerio-publico-face-a-indisciplina-no-contexto-escolar/ Acesso em: o5 ago. 2020.

O fenômeno bullying: breves considerações criminológicas sobre sua possível relação com algumas práticas da delinquência juvenil. MP de Minas Gerais, CEF, ano II, n. 7, out./nov./dez./2oo6. Disponível em: https://aplicacao.mp.mg.gov.br/xmlui/bitstream/handle/123456789/794/3.4.6\%20O\%2ofen\%c3 $\%$ b4meno\%2obullying.pdf? sequence $=\mathrm{I}>$ Acesso em:05 ago. 2020 .

CASES, Leonardo; JANSEN, Thiago. Bullying: um problema que extrapola a lei. Especialistas 
se dividem sobre a eficácia, a necessidade e os riscos da criminalização, proposta por comissão de juristas. 31 maio 2012.

Disponível em:<http://oglobo.globo.com/educacao/bullyingum-problema-que-extrapola-lei5o6645i>Acesso em: 21 ago. 2020.

CAVALCANTE, Meire. Como lidar com 'brincadeiras que machucam a alma'. Revista Nova Escola, São Paulo, ano XIX, no 178 , p. 58-6I, dez./2004

CHAUÍ, Marilena. Convite à Filosofia. 7. ed. São Paulo: Ática. 2000.

DEBARBIEUX, Eric; BLAVA, Catherine (Orgs.). Violência nas escolas e políticas públicas. Brasília : UNESCO, 2002.

DISTRITO FEDERAL. Lei no $\mathbf{4} .837$, de 22 de maio de 2012. Dispõe sobre a instituição da política de conscientização, prevenção e combate ao bullying nos estabelecimentos da rede pública e privada de ensino do Distrito Federal e dá outras providências.Disponível em: $<$ http://www.se.df.gov.br/?page_id=5544>Acesso em: 15 ago. 2020.

ELBOUX, Yannik D'. Escolas também são responsáveis por bullying. Gestão Educacional. Disponível em:

http://www.gestaoeducacional.com.br/sitege/view/action/visualizarMateria.php?cod=2187>.A cesso em: is ago. 2020 .

FANTE, Cleodelice Aparecida Zonato. Fenômeno "bullying": como prevenir a violência nas escolas e educar para a paz. Campinas: Verus, 2005.

FANTE, Cleodelice Aparecida Zonato; PEDRA, José Augusto. Bullyng escolar: perguntas e respostas. Porto Alegre: Artmed, 2008.

FANTE, Cléo. Brincadeiras perversas. Disponível em: <www.mentecerebro.com.br. Acesso em: I5 set. 2020.

FANTE, Cleodelice Aparecida Zonati. Entrevista: Os perigos do ciberbullying nas escolas. Disponível em: <www.conexaoprofessor.rj.gov.br/educacaoentrevista.aspEditeCodigoDaPagina $=4591>$ Acesso em: 15 ago. 2020.

GIANCATERINO, Roberto. $\mathrm{O}$ desenvolvimento e o julgamento moral humano. In:http://www.webartigos.com/articles/6759/I/o-desenvolvimento-e-o-julgamentomoralhumano/ Acesso em: 15 ago. 2020.

GIL, Antônio Carlos. Como elaborar projetos de pesquisa. 4 ed. São Paulo: Atlas, 2008.

GOMES, Marcelo Magalhães. O bullying e a responsabilidade civil do estabelecimento de ensino privado. Jus Navigandi, Teresina, ano 16, n. 2844, is abr. 2011 . Disponível em: 〈http://jus.com.br/revista/texto/r8907〉. Acesso em: 15 out. 2020.

GOMES, Luiz Flávio; SANZOVO, Natália Macedo. Mitos e verdades sobre o "bullying". Jus Navigandi, Teresina, ano 16, n. 2968, 17 ago. 2011. Disponível em: $\langle$ http://jus.com.br/revista/texto/19787〉. Acesso em: 2I set. 2020. 
GOMES, Luiz Flávio; SANZOVO, Natália Macedo. Bullying: o mais importante é a prevenção. Jus Navigandi, Teresina, ano 17, n. 3325, 8 ago. 2012. Disponível em: $\langle$ http://jus.com.br/revista/texto/22377〉. Acesso em: 2I set. 2020.

GOMES, Luiz Flávio. Bullying não deve ser combatido com legislação penal. Consultor Jurídico, o9 ago. 2012. Disponível em: < http://www.conjur.com.br/2012-ago-o9/coluna-lfgbullying-nao-combatido-legislacao-penal $>$. Acesso em: 15 out. 2020.

JARES, Xésus R. Educação para a paz: sua teoria e sua prática. Porto Alegre: Artmed, 2002.

JOAQUIM, Nelson. Direito educacional brasileiro: história, teoria e prática. Rio de Janeiro: Livre Expressão, 2009.

LAKATOS, Eva Maria; MARCONI, Marina de Andrade. Fundamentos de metodologia científica. 5. ed. São Paulo: Atlas, 2003.

LEÃO, Letícia Gabriela Ramos. O fenômeno bullying no ambiente escolar. Revista FACEVV. n. 4, Jan./Jun. 2010, Vila Velha. p. II9-135. Disponível em: < http://www.facevv.edu.br/Revista/o4/O\%20FEN\%C3\%94MENO\%2oBULLYING\%20NO\% 20AMBIENTE\%20ESCOLAR\%20-\%2oleticia\%2ogabriela.pdf $>$ Acesso em: is out 2020.

LOPES NETO, Aramis A. Diga não ao bullying. 5 ed. Rio de Janeiro: ABRAPIA, 2004.

LOPES NETO, A ramis. A. Bullying - comportamento agressivo entre estudantes. Rio de Janeiro: J. Pediatra, 2005.

MARCHESI, A. O que será de nós, os maus alunos?.Tradução: Ernani Rosa. Porto Alegre, RS: Artmed, 2006.

MARTINS, Maria José. O problema da violência escolar: uma clarificação e diferenciação de vários conceitos relacionados. Revista Portuguesa de Educação, I8 (I), 93-105, 2005.

MELO, Josevaldo Araújo de: Bullying na escola: como identificá-lo, como preveni-lo, como combatê-lo. Recife: EDUPE, 2010.

NERY Jr., Nelson; NERY, Rosa Maria de Andrade. Constituição federal comentada e legislação constitucional. São Paulo: RT, 2009.

PARANÁ. Lei no 17.335 de ro de Outubro de 2012. Institui o Programa de Combate ao Bullying, de ação interdisciplinar e de participação comunitária, nas Escolas Públicas e Privadas do Estado do Paraná. Disponível em: < http://www.legislacao.pr.gov.br/legislacao/listarAtosAno.do?action=exibir\&codAto=77838\&i ndice $=1 \&$ total Registros $=344 \&$ anoSpan $=2012 \&$ anoSelecionado $=2012 \&$ mesSelecionado $=0 \&$ is Pagi nado=true $>$ Acesso em: is ago 2020.

PEREIRA, Beatriz Oliveira. Para uma escola sem violência: estudo e prevenção das agressivas entre crianças. Fundação Calouste Gulbernkian. Fundação para Ciência e a Tecnologia. DINALIVRO. AUDIL, [ s.l.]: 2002.

PEREIRA, Bernardo Augusto da Costa. Bullying: implicações jurídicas e o papel do estado. [d.a. 20II]. CESUPA. Saber Jurídico. Disponível em: $<$ http://www.fabsoft.ce 
supa.br/saber/artigos/edicao3/artigo_4_bernardo_pereira.pdf $>$ Acesso em: I5 ago 2020.

PIAGET, Jean. A formação do símbolo na criança. Imitação, Jogo e Sonho.

Imagem e Representação. Rio de Janeiro: Zahar, 1975.

. A construção do real na criança. Rio de Janeiro: Zahar, 1976.

iNHELDER, B. Da Lógica da Criança a Lógica do Adolescente. São Paulo: Ed.

Pioneira, 1976.

PRADO, Adriana; AQUINO, Wilson. O que aconteceu naquelas salas de aula. In: ISTO É. 13 abr. 2011, ano 35, n. 216r.

SANTA CATARINA. Lei Estadual no 14.65I, de 12 de janeiro de 2009. Disponível em:< http://www.alesc.sc.gov.br/escola_legislativo/downloads/cartilhabullying.pdf >

Acesso em: II set 2020 .

SANTANA, Agatha Gonçalves. A necessidade do Direito de repensar o Bullying entre a criminalização e medidas de responsabilidade: Uma reflexão do caso realengo. Disponível em: <www.ambito-juridico.com.br> Acesso em: 1o set . 2020.

SALGADO, Gisele Mascarelli. O bullying como prática de desrespeito social: Um estudo sobre a dificuldade lidar com o bullying escolar no contexto do Direito. In: Âmbito Jurídico, Rio Grande, XIII, n. 79, ago. 2010. Disponível em: <http://www.ambitojuridico.com.br/site/index.php?n_link=revista_artigos_leitura\&art

igo_id=8172>. Acesso em: I5 set 2020.

SILVA, Geane de Jesus. Bullying: quando a escola não é um paraíso. Jitaúna, BA, 2006. Disponível em:< http://www.mundojovem.com.br/artigos/bullying-quando-a-escola-nao-eum-paraiso > Acesso em: is set. 2020.

SILVA, Ana Beatriz Barboza. Cartilha 2oro. Projeto justiça nas escolas. Brasília, DF: CNJ, FMU, 2010a.

SILVA, Ana Beatriz Barbosa. Bullying: mentes perigosas nas escolas. Rio de Janeiro: Objetiva, 2010.

Site oficial da cidade de São Carlos. Jovem que sofreu bullying espera que prática seja incluída no Código Penal. 27 jun. 2012. Disponível em:< http://www.saocarlosoficial.com.br/noticias/?n=Jovem+que+sofreu+bullying+espera+que+pra tica+seja+incluida+no+Codigo+Penal_76U88HX 5 DN $>$ Acesso em: I2 set. 2020.

SIMMONS, Rachel. Garota fora do jogo: a cultura oculta da agressão entre meninas. Tradução de Talita M. Rodrigues. Rio de Janeiro: Rocco, 2004.

TEJADAS, Silvia da Silva. Juventude e ato infracional: as múltiplas determinações da reincidência. Porto Alegre, RS: EDIPUCRS, 2007.

VALENTE, Ana Lúcia Eduardo Farah. A metáfora da guerra e suas implicações. Jus Navigandi, Teresina, ano I8, n. 3480, Io jan. 2012. Disponível em: 〈http://jus.com.br/revista/texto/23367〉. Acesso em: 15 set. 2020 . 